\title{
Economic Implications and Stakeholder Reactions in a Digital University Environment
}

\section{El impacto económico y las posturas de los actores principales en un ámbito universitario digitalizado}

\author{
Wolfram Laaser \\ FernUniversität. Hagen. Germany. \\ wolframlaaser@googlemail.com
}

\begin{abstract}
Substantial insecurity about the future of eLearning and particularly about the future impact of digitalization on the educational sector prevails at present. Those, who were enthusiastic at the beginning are now more sceptical about the future development of teaching with digital media, others maintain their positive attitude and are looking for ways to promote and implement their use in universities. Numerous institutions have published or are publishing forecasts and time frames about the relevance of the upcoming innovations. Less discussed are the economic implications that digitization may have on the universities' stakeholders and their decision making. In the field of online and distance education a descriptive approach of the costs and benefits has been so far predominant. Instead we will raise some points to initiate a discussion about the economics of digital educational resources and the possible reactions of and impact on teachers, students and institutions. We will also point out some of the long-term effects that digitalization of education might have on a global level.

Concluding that digitization followed a continuous development pulsed especially by universities of distance education and that phenomena such as MOOCs are not as "disruptive" as some claim. Instead, national policies, economic sustainability and the impact of digitization on different stakeholders will determine the future form of the "Digital University" in case such a university exists.
\end{abstract}

Keywords: Economics of online courses, digital content, Distance education, Digitalization, eLearning, Online courses, MOOCs, Digital University, Globalization.

\footnotetext{
Resumen

Actualmente predomina una sustancial inseguridad sobre el futuro del eLearning, y en particular sobre el impacto de la digitalización en el sector educativo. Muchos que al inicio se mostraron entusiastas ahora son más escépticos sobre el futuro desarrollo de la enseñanza mediada por tecnología, mientras que algunos mantuvieron su actitud positiva y siguen buscando formas de promover e implementar su uso en las universidades. Menos discutidas son las implicaciones económicas que la digitalización puede tener sobre las partes interesadas de las universidades y su toma de decisiones; mientras que, en el campo de la educación a distancia en línea, un enfoque descriptivo de los costos y beneficios ha predominado hasta ahora.

Partiendo de la crítica sobre el criterio metodológico empleado en algunos estudios, se discutirá el posible impacto de la digitalización en una futura universidad digital desde tres ángulos diferentes: una perspectiva histórica, una perspectiva económica, y las actitudes de los actores y sus características. En el pasado el análisis descriptivo de costos y beneficios de los cursos en línea era la forma predominante para analizar la eficiencia comparativa de diferentes sistemas de educación. Al contrario, queremos focalizar algunos puntos claves para incentivar un debate sobre la economía de recursos digitales y sus efectos sobre los respectivos actores principales (stakeholders). Además, trataremos perspectivas a largo plazo respecto a los efectos de la digitalización de contenidos educativos en un mundo global.
} 
Concluyendo que la digitalización siguió un desarrollo continuo impulsado particularmente por las universidades de educación a distancia; y que fenómenos como los MOOC no son tan "disruptivos" como algunos pretenden. En su lugar, las políticas nacionales, la sostenibilidad económica y el impacto de la digitalización en las diferentes partes interesadas, determinarán la forma futura de la "Universidad Digital", en caso de que tal universidad existiera.

Palabras clave: Economía de cursos en línea, contenido digital, Educación a distancia, Digitalización, eLearning, Cursos en línea, MOOCs, Universidad digital, Globalización.

\section{Introduction}

The difficulties in forecasting the future characteristics of a digital university profile lie in the fact that the technological development is very fast; and in the underlying economic and political influences which frequently change after elections. Therefore, the reliability and validity of such forecasting attempts is not easily assessed. In addition to that, the methodology; i.e. how the data and published outcomes are generated is rarely documented in detail. Most of the studies are based on questionnaires filled in by educational stakeholders or "so called experts" (examples of this type of research are Allen \& Seaman (2013); Hart (2015); for a critique of the Horizon Report see (Baggaley 2013).

We will therefore not add another forecast. There are already a sufficient number on the market. Instead we will focus mainly on a small educational subsystem, the universities, and discuss the different options and the stakeholder attitudes which will impact on the future "digital university", assuming, that something like a digitalized university may then exist.

\section{Historical flash back from Distance Education to Blended Learning}

The Distance Education Universities were among the first to apply digitalization to development and distribution of educational content. For example, the German Distance Teaching University of Hagen started already in the early 1980ies experimenting with text processing and computer conferencing as early as the beginning of the 1980s (Laaser 2017). Later didactic computer simulations, online courses and virtual laboratories have been developed. Digitalization allowed for a very close integration of the various media. Pushed by the developing internet, digital media such as pdf files, podcasts or webcasts et cetera were added and integrated into complex learning management systems that also provided web spaces for simultaneous or delayed communication.

The media development in distance education and the potential of the world wide web forced the conventional universities to keep up with the rapid development and to make greater use of the new facilities for teaching and learning. With regard to the learning management system it turned out that these systems initially isolated from administrative data banks. Put together, learning management systems and the integration of smooth data linkage with administrative processes such as matriculation, certification, lecture schedules and costing led to the complete campus management systems that are in use today. This development is still ongoing and has a great potential for future development (Shacklock, 2016)(Kaltura 2018).

Since the end of the 90ies institutions have been able to facilitate the production and distribution of teaching content could be provided at very low cost via learning and campus management systems, conferencing facilities and network services, enabling conventional universities to adjust their teaching model, thus permitting the integration of off campus learning and teaching activities into

Economic Implications and Stakeholder Reactions in a Digital University Environment. Wolfram Laaser

Página 2 de 20 
their programmes. The outcome is for most universities at present a mixed mode system labelled "Blended Learning" which includes recordings of online lecturing activities, mediated self study, group work and face to face activities. At present the mix of these system components vary across universities and even between departments or chairs. The term "Blended Learning" however, is another example of a buzzword which very practically does not exclude any of the present mixed mode types of teaching and learning. In condition we can state, that the innovation called "distance education" has finally trickled down to some extent to the entire educational sector, al least to some extent or other. Thus the spread of digitalization is going to replace "distance education" as a specific teaching model.

\section{Some Economics of the "Digital University" The heritage of Distance Education}

Distance education had since its early years already applied a type of industrialized pattern of development, production and distribution, which included course development teams, modular teaching units and professional management and organization. The digitization and the web changed the cost structure step by step for the conventional universities as well, turning from investment in "Brick and Mortar" to investment in content, IT and the training of staff. The inexpensive, or free digital web tools allowed for a more decentralized mode of production and distribution of digitized media. The communication technology changed from "one to many" to a "networked community" with different clusters which also include social networks outside the university.

Wagner (1972) showed that the cost per student at the British Open University, the famous distance teaching university, is about one third of that of the other conventional British universities.

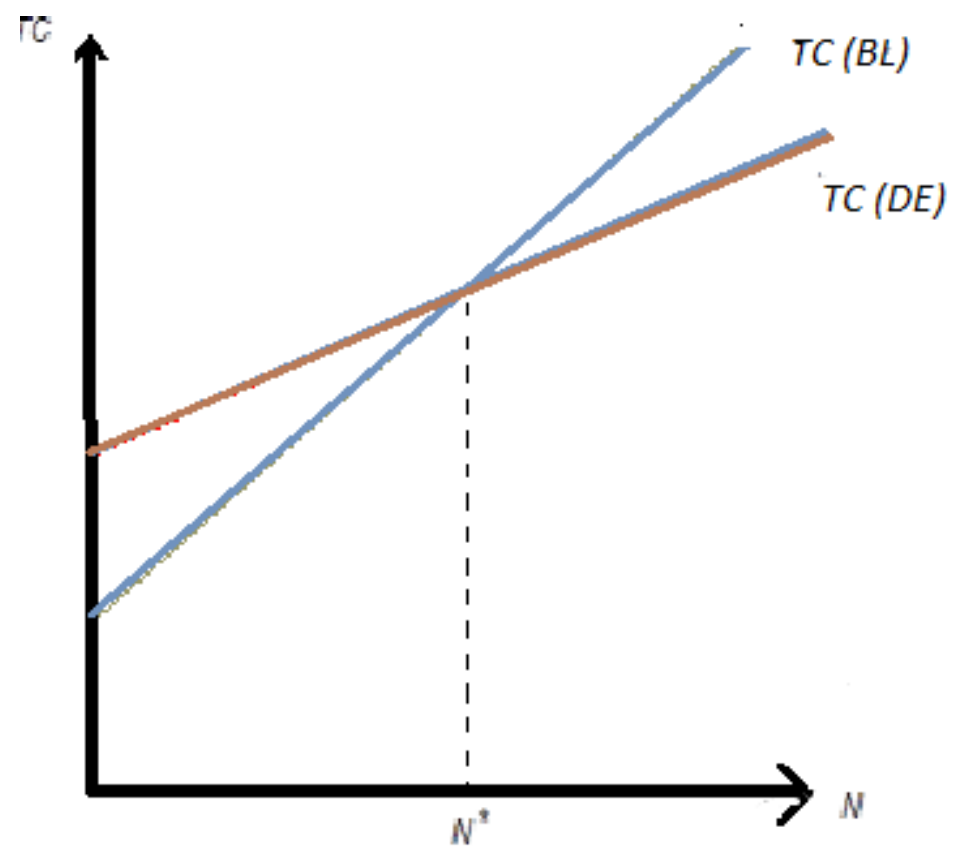

Fig. 1 Cost of F2F and Distance education (according to Wagner (1972))

Symbols used:

$\mathrm{TC}=$ Total Cost $; \mathrm{F} 2 \mathrm{~F}=$ Face to Face $; \mathrm{DE}=$ Distance Education $\mathrm{N}=$ Number of Students

Economic Implications and Stakeholder Reactions in a Digital University Environment. Wolfram Laaser

Página 3 de 20 
It can be observed from the diagram, that there is indeed an enrollment level at which distance education becomes cheaper than face to face education. Whether distance learning can really be sketched as shown in the diagram is debatable, because also output quality and other factors might also be relevant for the comparison (e.g. Yenbamrung 1994).

\section{Blended Learning}

In any event, what has been presented by Wagner is not equally valid for todays blended scenarios. The introduction of phases of self-study by recording of lectures or other digital material (flipped classroom model) needs specially equipped lecture halls, the training of teachers, the acquisition and updating of software and probably permanent technical support services for teachers and students. These costs can be balanced against some cost reduction for on campus lecture halls and other local assets. Though, with adequate training and reasonably good recording facilities digital content and online support can be done by the teacher and students themselves.

One of the general problems of blended learning, as its mixture of predetermined face to face meetings with phases of autonomous learning per digital media and webtools. When determining the pacing of individual learner progress, increasingly heterogeneous learner experiences have to considered. This holds especially for the Massive Open Online courses offered initially by some leading US universities (xMOOCs). The coordination, especially with respect to possible F2F meetings, is difficult and time consuming for both teachers and learners (Shah, 2017). Individualization requires free timing of ones own ctivities, which can also conflict with collaborative learning tasks. Thus, a system which concentrates heavily on network based instruction and collaboration, and is exclusively online without face to face meetings or fixed schedules for simultaneous communication, will still be an economically attractive alternative. Most probably the relatively strict mix of online and offline phases will not achieve comparable cost reductions to those known from the former distance education systems.

Economic Implications and Stakeholder Reactions in a Digital University Environment. Wolfram Laaser

Página 4 de 20 


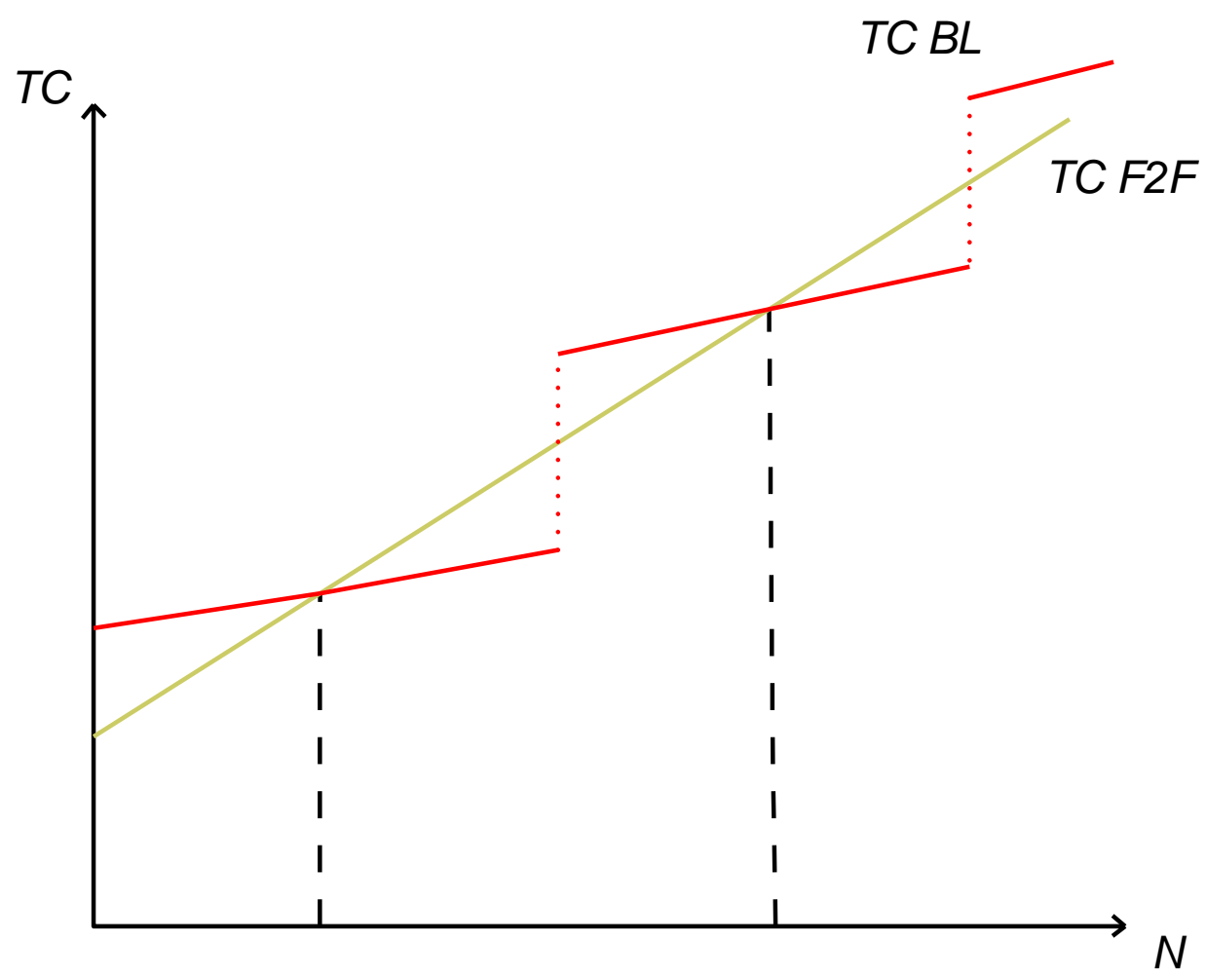

Fig.2: Total Cost of a Blended Scenario

Due to regular phases of self study an increase in student numbers will require less additional lecturing hours than in a fully F2F teaching model. In this manner part of the workload is transferred to the students. However, a jump of fixed costs will happen from time to time caused by the additional cost of lecture halls, recording and editing facilities once the actual capacity in terms of recording facilities or meeting rooms for F2F meetings is exhausted. In addition, there are still some variable cost such as operational cost of the platform or necessarysoftware updates to be covered. Multiple break-even points are possible. Furthermore there is a certain trade off between scalability, educational quality and the share of simultaneous communication. Every type of simultaneous communication, be it electronically or face to face, is hampering the full exploitation of economies of scale due to the expensive time of face to face lecturing and to the rigid schedules which reduce invidual flexibility in organizing learning activities (Laaser, 2008).

\section{The "disruptive evolution" of MOOCs - Are they sustainable?}

To extend on some of the arguments above we will look at the actual debate about MOOCs (Massive Open Online Courses). MOOCs seemed to be a low-cost alternative to conventional lectures. The massive number of enrolled students in the first xMOOCs (MOOCs offered by leading US universities) were not supported by tutors or lecturers. They received streamed or downloadable video lectures and some multiple-choice tests. Initially the development and running of MOOCs was funded by large grants in the US so that the programmes could be offered free of charge. But after funding cuts the universities

Economic Implications and Stakeholder Reactions in a Digital University Environment. Wolfram Laaser

Página 5 de 20 
had to look for other sources of financing. If there is no special permanent budget for MOOCs allocated, the activity has to generate some own revenue to cover the development cost of new courses and pay for the platform operation. However, with increasing enrollment and the increasing heterogeneity of the participants the necessity of offering more specific support services such as online videoconferencing or additional F2F tutorials will increase costs and, in the event of their not being provided, will lead to high drop out rates. So, MOOCs will either loose one of their constitutive attributes - being free of charge - or without special funding they will be restricted to offering a limited number of short "low service support quality" courses with high enrollment numbers and drop out rates, and to hoping to be compensated by some image gain that may lead to new enrollments in other courses. Udacity and Coursera have already given up their initial policy of offering certificates or tutorials completely free of charge. In this case the number of students will be more limited and the xMooc will finally turn out to be just a regular offer differing in not requiring a respective entrance qualification and taking participants who are not a student of the university. As expressed in a report by Siemens "The sheer scale of numbers of students led to bold proclamations of education disruption and a sector on the verge of systemic change. However, from the perspective of 2015, these statements appear increasingly erroneous as MOOCcs have proven to be simply an additional opportunity instead of a direct challenge to higher education itself" (Siemens et al. 2015, p. 6).

The MOOC programmes therefore, are more representative of a marketing strategy by which some of the university's teaching content is provided for free as an appetizer. It is certainly fascinating to think about free access to internet screencasts or classroom lecture recordings, which can be viewed at real time or later by an nearly unlimited number of students from a webpage at minimal costs or for free as the marginal cost for distributing an additional lecture copy tends to be zero for the institution. Thus, the old economies of scale seem to re-appear to a certain extent.

\section{Digitalization and Markets for Education}

We will extend our discussion about the impact of digitalization on a future gobal educational market. A university which bases its teaching mainly on digital media, shows some similarities with the costing characteristics of the software industry. 


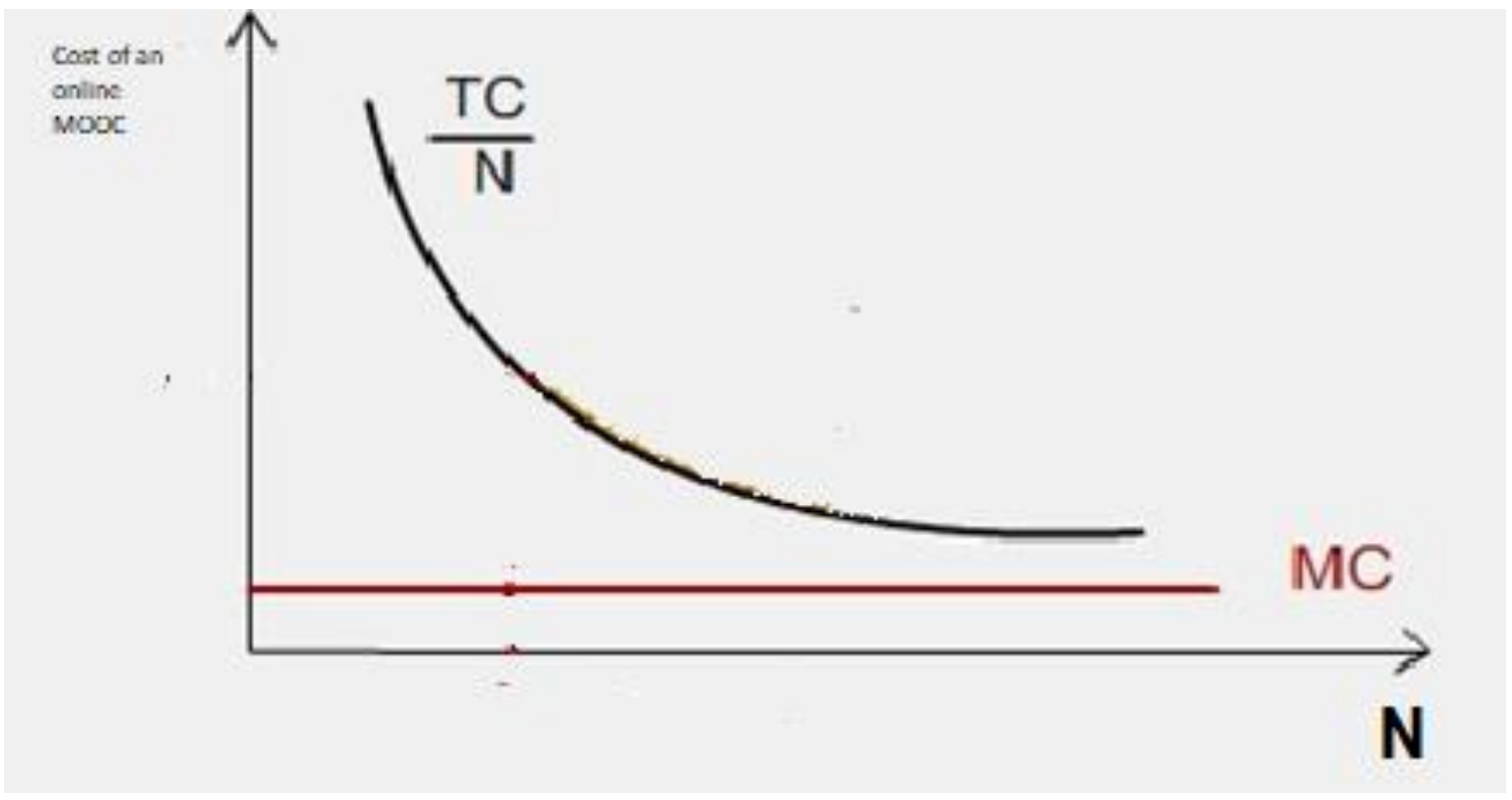

Fig. 3: Marginal and average total cost of software (taken and modified from Shy (2001)

Fig.3 sketches a situation where the cost of setting up a MOOC per student enrolled or by number of graduates) is mainly dominated by the fixed initial investment cost and is characterized by very low operating and distribution costs (MC). Total costs per student decrease as the number of students participating rises. Decreasing average total cost with rising enrollment numbers and low variable cost has also been one of the main reasons for the fast growth of distance teaching universities. Some of the distance education universities became even mega-universities. Will the same happen in a digitalized university environment?

In case of cost structures as sketched in figure 3 and 4 the competition among private providers in the market for relatively homogeneous educational offers (such as an online Master in Business Administration) will drive the market price down to marginal costs.

Economic Implications and Stakeholder Reactions in a Digital University Environment. Wolfram Laaser 


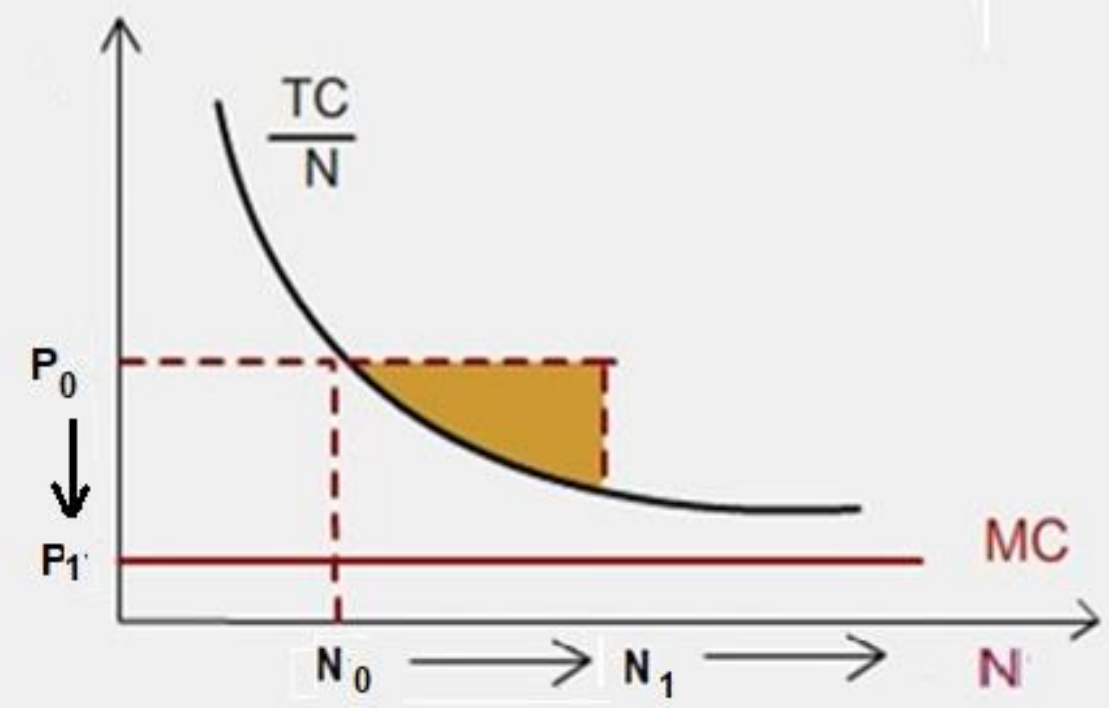

Fig. 4 Competion and Fees in a Market for MOOCs (source author)

Once a digital content module is developed for the market, the initial development cost of a MOOC is considered as fixed cost (independent of output level) and if the investment has already been executed, this is designated as "sunk cost". However, the sunk costs are not considered relevant for short term price setting. If the marginal costs of servicing an additional student are extremely low, the suppliers will not be able to recover their long term total cost by raising fees from students. In this situation the production of a MOOC is only possible if the difference between the fee at marginal cost and the total average cost is covered by external resources. Otherwise, the competition among suppliers will lead to a self destroying process by which the production generates individual losses.

The xMOOCS were initially financed by external funds and benefitted from existing knowledge and content in the departments. If an enterprise (educational MOOC provider) survives this phase of losses, it will try to kick out the remaining competitors and having achieved that will set a price which maximizes profits (case of a dominant private university). Extreme profits will attract new competitors and in the case of a private university its potential profit will also be limited by the existence of public universities. The cost of entering the market in the case of software, or in our case of educational digital content, is relatively easy. Therefore market entrance is relatively easy. This may, in addition, be may be, in addition, be fired by the so called "snowball" effect (the utility of a product rises with the number of users). These are important factors that will prevent a single provider from gaining excessive profits..

However, existing supply-side monopolists or oligopolists will defend their market share by spending high amounts of money on public relation campaigns to increase the visibility of the university. Another protective strategy is to buy out the newcomers before they become an important rival. In economics such market structure is called a "natural supply side monopoly" as all other solutions would increase average total costs. These markets are often under government control.

Economic Implications and Stakeholder Reactions in a Digital University Environment. Wolfram Laaser

Página 8 de 20 
A non profit university has to set prices or fees at a level that meets more or less the respective average total cost for a targeted matriculation level if no external resources are available. The motivation to extend enrollment beyond the actual level N0 is not very high as it would imply that possible savings would have to be re-invested to bring profits back to zero. However, the investment may increase the university's/institute's reputation, or provide a better chance to recruit excellent students.

A public university has to finance the development costs from its yearly budget allocation. So if it wants to run free MOOCs, it has to reduce other important activities. Therefore the share that MOOCs are allocated as part of the entire teaching activities will remain quite limited and has to be justifiyable against the internal claims of the administration and departments..

Furthermore, with massive additional enrollment, the quality of the current services may after a short upswing, due to the possibility of contacting a manageable group of costudents - deteriorate later on because there mlght be congestion in accessing tutorials and technical support if enrollment figures becomes very high. The diversity of entrance qualifications, language abilities, cultural patterns et cetera will probably also increase with massive enrollment figures. So, without extending support services the quality of the course will diminish and the willingness of students (marginal utility) to pay extra fees will fall.
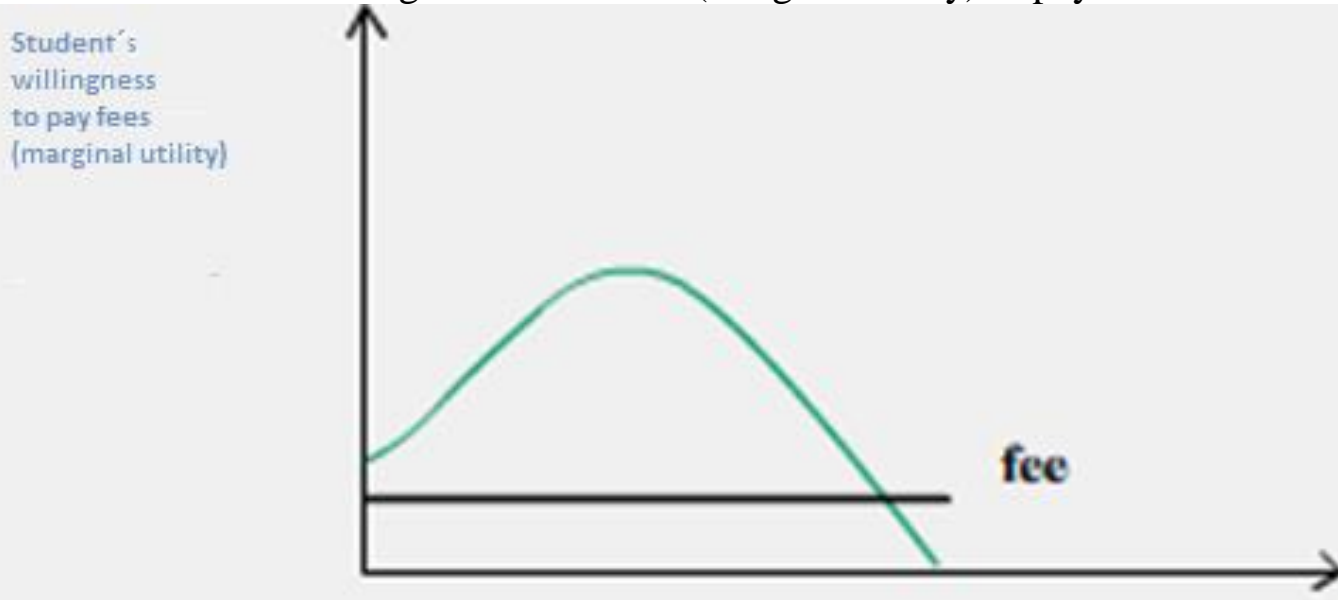

Fig. 5 Fee and students' marginal utility (source author)

Enrollment will then be lower and dropout will increase. Students will enroll according to the utility they get from the MOOC and they will compare the MOOC with similar offers of content providers and consider also the cost of F2F lectures at a nearby university. If enrollment is free, then demand to enroll will be at maximum of interested students. However, the motivation to continue studying in the free MOOC will be probably become less at very high enrolment numbers as the zero cost of exit makes dropout less harmful for students.

Economic Implications and Stakeholder Reactions in a Digital University Environment. Wolfram Laaser

Página 9 de 20 


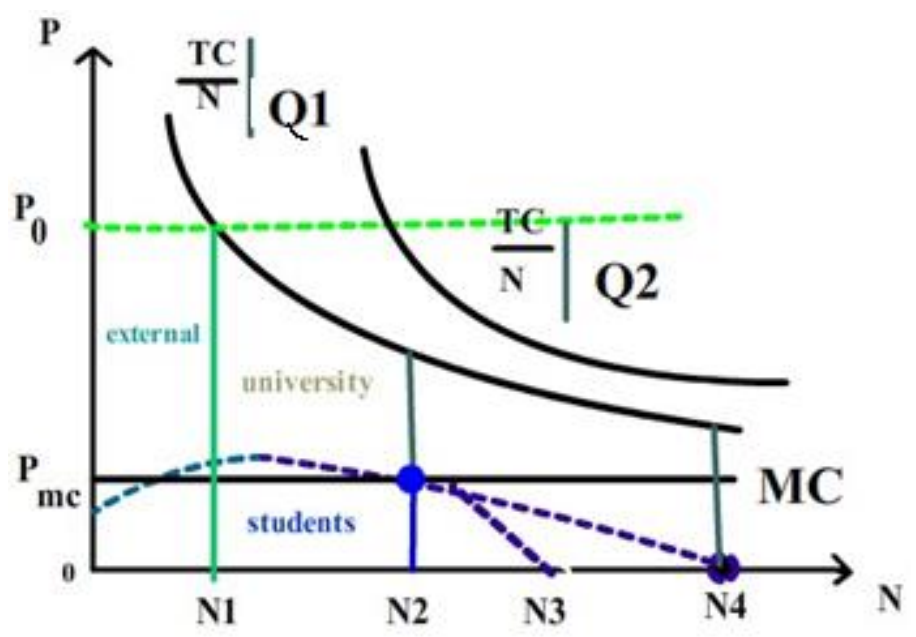

Fig. 6 Fees, costing and students' willingness to pay (marginal utility)

Students will easily drop out more easily if the fee is above their marginal willingness to pay.

The fact that the first xMOOCs were offered by some leading universities free of any study fee and thereby reached very high enrollment figures is not surprising, though the pedagogical design followed old behaviouristic patterns. Another advantage of the first xMOOCs was, that they were not yet confronted with other competitive offers.

The government or other institutions may consider the digital MOOC as a public good, (example given: a MOOC offered for refugee language training) and subsidize its production up to a certain estimated output so that the digital course can be offered free of charge to students. However, this will hold only for special funding initiatives..

Let's assume that the subsidies are limited to a targeted enrollment of $\mathrm{N}_{1}$, thus largely covering the course development cost which can be regarded as the fixed cost of the MOOC including the marginal cost such as payment for platform usage.

In the short run a socially preferred situation would be reached if the level of fees equals marginal cost. However, a university's sustainable offer has to cover the entire total cost, reduced in part by raising special study fees that cover marginal cost.

The universities, though, will most probably not even be able to cover the complete variable costs. They will try to save costs either by lowering quality, by further digitization of administrative and developmental processes or by asking for higher special fees to maintain or extend the initial level of quality, which could be provided by tutorials or other current services. Therefore, the pressure of financing the MOOC by fees is increasing with massive enrollments. As fees are already very high, at least in the U.S., a further significant increase may be difficult to accomplish.

As argued before, the upcoming MOOC market will show some inherent tendency to extend its scale to a level where only a few players are left.. A comparable tendency towards high market concentration can be observed in digital academic publishing, where a similar cost structure prevails. According to Larivière, Haustein, \& Mongeon (2015) since the advent of the digital era of the mid 1990ies the leading publishers have increased their

Economic Implications and Stakeholder Reactions in a Digital University Environment. Wolfram Laaser 
share of the scientific output published. In 2013 about $70 \%$ of the papers published in social sciences were from the top five publishers.

To save themselves from having the own development cost of a platform for MOOCs, several universities in the U.S. use a common platform like Udacity or EdX for distribution of their xMOOCs (for economies of scope see Li \& Chen, (2012)). However, it is already visible that at least in Europe there will not be just one common "European MOOC platform" and probably not even a common national platform - as announced by the Norwegian Ministries. Development of such a platform need not be very expensive - e.g. it can be created with Moodle - and can then be better tailored to the needs of smaller and more homogeneous institutional groups (Creelman, 2014), (Cooch, Foster, \& Costello, 2015).

Nevertheless, public budgets are being put under pressure by the rising expenses for education, because they are expected to cope with salary increases keeping them on par with corresponding increases in the private sector. This is a problem that applies to the public universities as well. The consequence will be, that the cost intensive parts such as tutoring will be replaced to a great extent by interaction with robots or bots. Substituting lecturing time and evaluation for student's peer collaboration and evaluation is not a convincing and efficient solution. The time which students will need to organize themselves into creating meaningful collaborative learning activities might lengthen study time and thus lead to a longer graduation period. Furthermore, regarding the use of artificial intelligence in the light of past experience, it is uncertain as to what extent human dialogue can be replaced by interaction with humanized robots (see in this context Endlich \& Sohoi, 2017). Higher education is a segment of the educational sector, where repetitive processes or dialogues are less frequent and where appearance, tone of voice, corporal expression and so on are important to establish a good rapport.

At first sight it would appear reasonable to somehow standardize the MOOCs according to various criteria and thereby create a more transparent educational market that allows for the mutual accreditation of universities. If such were the case, negotiations could then help universities to round off their curriculum by adding special parts that would be too expensive for one institution to produce alone.

There is not yet much standardization visible $\mathrm{n}$ the U.S.A. and no common credit point system is in existence. The American educational system of higher education is characterized to a great extent by private universities and foundations. Thus, after initial funding the former free of charge MOOCs, which were offered by the more prestigious universities, had to create their own income by certification fees, by charging for tutorial support or even by selling student data to other institutions.

In contrast to the US, Europe has already made some progress in the standardization and accreditation of careers with the ECTS (European Credit Transfer System) classification system. Apart from that, the number of public universities in Europe is much larger than in the U.S. However, the problem, just as in the past, is that cooperation between universities is still very deficient across national borders because of existing social, cultural and legal differences. Therefore, the market for MOOCs is not yet sufficiently developed. Furthermore, an early standardization or regulation could hamper innovations.

Futurists like Jeremy Rifkin (Rifkin, 2016) claim that the low cost of educational media, distributed nearly at marginal cost will challenge the existing monopoly of knowledge that

Economic Implications and Stakeholder Reactions in a Digital University Environment. Wolfram Laaser

Página 11 de 20 
the traditional university still represents. The public university is a service provider that will be replaced increasingly by individual access to teaching content at zero cost which can also be created, shared and evaluated in collaboration with ones peers.

The hope, expressed by Rifkin and others, that the capitalist market economy will be transformed into a society where collaborative groups, commons and sharing of selfproduced goods and services dominate seems to be still unrealistic both from a viewpoint of the dynamics of a market economy and by taking the actual distribution of economic power into account. It seems rather that the public educational sector will become more dependent on the policy of the huge international companies.

What are the more specific effects of digitization, networks and IT on online teaching universities? We will discuss this by distiguishing the impact according to the stakeholders of the university, namely the external ones, such as Ministries of Education and Industry and the internal ones, comprised of the central leaders (Rector, CEO et cetera.), the administrative staff, the teachers and the students.

\section{The Impact of Digitization on the Stakeholders}

\section{Students}

Students are supposed to become digital literates, able to identify and use the resources of the web, they are expected to learn to create content and to communicate and cooperate via the web. They are expected to check the correctness and credibility of web information and they should make creative use of the new options for ubiquitous learning. If these objectives have already been pursued during school education, we might then get a much more autonomous learner; one who is able to acquire the competences the European Community deems essential (see e.g. Williams, Kear \& Rosewell, 2012).

However, what will the "dark side" of this changed ecology be? Social cohesion and interaction of students with their direct social environment will be less and will in part be substituted by the virtual identities of peers which may deviate from their real identity. A new culture will emerge that integrates the real and the virtual world. Presentation of their personality and activities in social networks can be a sign of a narcissistic culture. Students will sympathize or not with people they know only by their virtual identity. This opens-up a big potential for seduction and distribution of hidden or faked information and ideologies (World Economic Forum, 2016).

Furthermore, learners will be more distracted when reading from screen as the information they are used to receiving is diverse in design, sources and context. Consequently, they might experience some difficulties in concentrating on a problem for a longer period. Brabazon describes the problem this way:

"As each semester progresses, a greater proportion of my students are reading less, referencing less and writing with less boldness. There will always be the top $25 \%$ of the class who are rigorous and committed scholars in the making. They can operate in the models of student-centered learning. Increasingly the middle fifty per cent, who require greater guidance, attention and commitment from the teaching staff to pass a course, is producing inadequate stuff...These problems are not caused by Goggle. Instead, the popularity of Google is facilitating laziness, poor scholarship and compliant thinking"

Economic Implications and Stakeholder Reactions in a Digital University Environment. Wolfram Laaser

Página 12 de 20 
(Brabazon, 2014, chapter 1, p. 1). Morgan cites another interesting aspect referring to Hassan, which is the intensification of time expressed by the label "network time".

"The more we inhabit the network - on a PC at work or at home, on a PDA on the train, or in the street with a mobile phone clamped to the ear - the more we inhabit its temporally accelerated domain, with its potentially disorienting and frenetic pace" (Hassan, 2004, p.28).

According to Hassan, network time leads to chronic distraction. Students will face an academic environment where social objectives and academic scholarship are, inter-twinned with an increasing number of commercial influences, be it at school, home or workplace, especially if we look at social networks. Therefore students will bring better technical knowledge with them, when they start studying but will have deficits in other domains.

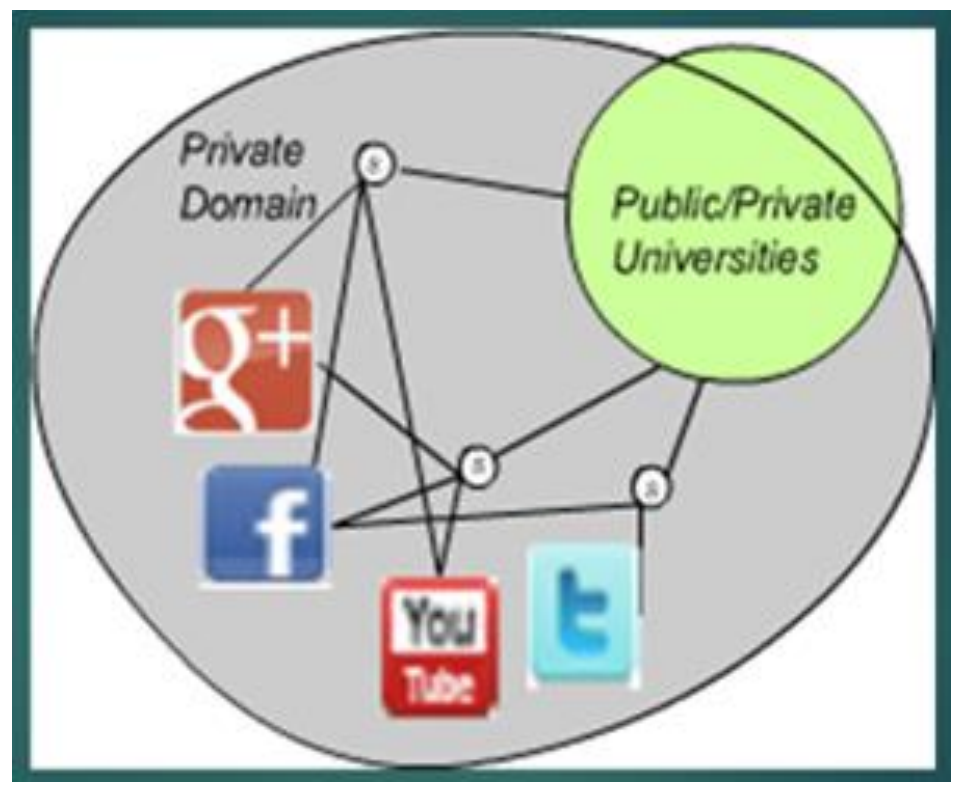

Fig. 7: Social ecology of networks and universities

\section{Teachers}

In the digital university world university teachers are supposed to become facilitators, media experts and actors in front of a camera, knowledgeable users of web 2.0 tools and finally keep up to date with their own academic field of teaching. Rumble writes: "However, a division of labour is likely to occur because in the long run any system that limits control of design and delivery to a single person limits both the range and sophistication of the materials that can be developed, and the number of students that can be supported, and is thus inherently cost-inefficient given the much greater economies of scale in systems designed for the division of labor" (Rumble, 2001, p 77). It is obvious, that the teachers will have difficulties in fullfilling all these demands. So, this problem will lead to the splitting up the teacher's role into different tasks carried out by a respective specialist, for example some of the lectures at Khan Academy are recorded with professional speakers or actors instead of the teacher's voice. In most cases the recorded lectures will not have the dynamics of a real live lectures, because the teachers will be

Economic Implications and Stakeholder Reactions in a Digital University Environment. Wolfram Laaser 
aware of the fact, that the material will be multiplied and distributed to a greater number of users.

One implication will be that some teachers will oppose having to take over a role that reduces their traditional autonomy. Those who accept the changing role will take over a specialized task and will enter a system of coordinated professional production of teaching content. They will thereby follow the roads of early division of labour in distance education. A certain difficulty attached to the role of being just a facilitator, lies in a tendency to present or moderate the views of other authors and not to develop one's own view. The saying that "you do not have to reinvent the wheel" is in a way not valid, because in the process of reinventing, the knowledge embedded in the invention is reconstructed by the teacher and thus better understood by himself/herself.

Another issue of importance is the trust that students will have for their teachers. In a time where many of the traditional functions of a university teacher are covered on the surface by content in the web or are accessible from the crowd of peers, the teacher will have to fight to establish credibility. Students seem to trust their co-students more often and more readily than they trust their teachers, with time they even prefer to put their trust in search engines (World Economic Forum, 2016). Therefore at least some face to face contact is very important to create a good emotional relationship between the students and the teacher.

\section{The Educational Policy Makers}

Educational policy makers are usually interested in limiting educational expenses without losing efficiency. In a digital university environment they will have the new option of using the available "big data" to influence and manage the entire sector. Formerly the main information items were enrollment data, number of graduates and programmes, salaries of employees and a number of research publications. The huge quantity of digital data made available by checking all workflow processes in detail, offers ample possibilities to relate the different data and use them as inputs to manage the sector or the institution.

An important precondition is that data banks are compatible in their definitions and that programs to aggregate these data can be properly handled. To be effective the digitalized university needs to redefine IT supported processes which often implies structural adjustments towards decentralisation of the normally hierarchical organization of the academic and the administrative workflows. Otherwise it will not be able to react quickly and flexibly to the changing environment (Laaser, 2011). Although some interviews with the leading staff of four European Universities have been conducted recently, the results seem to be conflicting and the strategies towards innovations still remain rather vague (Bell, Douce, Caeiro, Teixeira, Martín-Aranda, \& Otto, 2017).

\section{Globalization of Higher Education}

Who is interested in digital education? Is it the individual learner, the teaching staff, the consumer or is it mainly the industry? As pointed out already, there is hardly any academic discipline that is so closely related to industry as is educational technology. Most of the academic conferences on educational technology are accompanied and sponsored by an exhibition of software and hardware vendors. The interest seems to be mainly in finding out how educational applications can be identified and applied with the new products

Economic Implications and Stakeholder Reactions in a Digital University Environment. Wolfram 
developed for the consumer market. The result is that critical issues such as detecting hidden ideologies or ethical problems embedded in vendor strategies are not very frequently researched. Buzzwords come and go at ease and keep the academic community going.

Today we observe that the global educational market is the target of the big educational technology providers. Online translation is getting faster and easier to access. Superficial localization has become faster and easier. Though, a lot of underlying ideologies are often embedded to describe, for example globalization issues by expressions such as "global village" or "the world is flat" thereby neglecting the substantial regional and cultural differences.

The notion that the individual can best control his/her learning progress, implies that the authority represented by the teacher is considered to be an obstacle rather than being a partner or facilitator. The same ideology underlies the claim that the crowd or peer group is the better teacher. The state and its academic institutions have to return to a policy that represents the social needs of the entire society. These needs do not automatically coincide with the interest and goals of the industries, or as Audray Watters puts it: "After all, for many people edtech is a business, one that is quite excited by the prospect that - perhaps thanks to technologies - education itself is looking more and more like a private, consumer product rather than a public good. I think we must rethink both education practices and systems alongside our challenges to edtech as corporatisation and privatisation. Education technology is, after all, a series of practices itself - it is not just the hardware or software. Edtech carries with it ideologies and ideas" (Watters, 2017, par. 7).

Rifkin wrote in his book "'The Zero Marginal Cost Society", that in contrast to Stanford's students, who have to pay a fee of about 50.000 \$ per year, the Udacity Online University had the objective of offering free university education for all, especially for the poor in developing countries" (Rifkin, 2014, p.171). The fact that online courses which are unsupported, and unlocalized, would represent a solution to the educational problems in developing countries, even if offered free ofcharge, is at best naive and reminds us of the "One Laptop per child" initiative of Negroponte.

MOOCs were conceived as a medium to ease access to for everybody, meaning to socialize a commodity that was before only accessible to a few. It is true that U.S. universities' knowledge was opened-up a bit and was exported internationally at a subsidized price. It will probably lose some of its academic rigour and relate learning closer to edutainment accompanied by commercials (Bradford \& Loble, 2016).

The xMOOCs have been criticized by the European Union for their low support of the teaching content delivered mainly by recorded lectures (EADTU 2015). Furthermore recording just a lecturer performing in the classroom means that audiovisual standards have even fallen back compared to earlier multimedia developments in Distance Education (Laaser \& Toloza 2017). However, in Europe the national differences are substantia, but without special funding MOOCs will not survive neither in the U.S. nor in Europe.

\section{Summing up}

In this article, we have tried to show that the future of a "digital or digitized university" can be grounded on development and application of digital teaching media that had already begun in the 80ies and thus created the basis for a future digital university. Considering the

Economic Implications and Stakeholder Reactions in a Digital University Environment. Wolfram Laaser

Página 15 de 20 
recent development of MOOCs as a revolution or disruptive change of the way we learn and teach cannot be confirmed. The $\mathrm{x}$ MOOCs certainly gave a kick to digital content development but will not become the "face " of a digital university. We have discussed the offer of open and free courses from an economic viewpoint and pointed to some alternatives of how to finance them. We then used findings of network economics to derive some consequences for the structure of a future global market of educational digital content. The digital university will finally depend on the actions of the stakeholders, not on crystal gazing with ever new and contradictory forecasts.

The discussion of the possible influences has shown that the future is still full of conflicting ideas and contradictions. A simple modernization paradigm according to which the educational system has only to invest into the latest technology will be misleading. History is steered by the interests of stakeholders and by their conflict solving and cooperation ability. Economic considerations have a crucial influence on this process.The important decision is, to what degree education should be offered free of charge as a public commodity or sold to private custumers. Unfortunately the evelopment of the MOOC provides no helpful guidelines for this decision, however it marks a trend.

Educational network technology is based on the idea of a free economy and education will increasingly be regarded as a tradable good. Thus, governments are supposed to privatize the educational sector, though education so far has been considered a public commodity and not to be determined by special interest groups. As the characteristics of educational software have some tendency towards natural monopolies we expect a global educational market controlled by a few big players such as Google, Facebook or Twitter. Whether this becomes our future, depends very much on the universities, their teachers and students fighting for their interests, and for being allowed to determine change themselves. What the outcome of these struggles will be for a future "digital university" can hardly be determined by crystal gazing.

\section{Acknowledgements}

The author is grateful to F. Schaffer for an enriching discussion of the economics part and thanks to E,A, Toloza for helpful comments and editing support.

\section{Disclosure statement}

No potential conflict of interest was reported by the author.

Submission of the article: December 2, 2017

Date of approval: March 15, 2018

Date of publication: March 31, 2018

Laaser, W. (2018). Economic Implications and Stakeholder Reactions in a Digital University Environment. RED. Revista de Educación a Distancia, 57(4). Consultado el (dd/mm/aaaa) en http://www.um.es/ead/red/57/laaser.pdf

Economic Implications and Stakeholder Reactions in a Digital University Environment. Wolfram Laaser 


\section{Funding}

This research received no specific grant from any funding agency in the public, commercial, or not-for-profit sectors.

\section{References}

Allen I. E. \& Seaman J. (2013). Changing Course. Ten Years of Tracking Online Education in the United States. Babson Survey Research Group and Quahog Research Group, LLC

Baggaley, J. (2013). When prophecy fails. Distance Education Vol. 34, No. 1, p. 119-128

Baggaley, J. (2016). Sandcastle competitions. Distance Education Vol. 37, No. 3 366-375)

Bates, A. (2014, July 27). Why lectures are dead (or soon will be). Blogpost: Online Learning and Distance Education Resources. Retrieved from https://www.tonybates.ca/2014/07/27/why-lectures-are-dead-or-soon-will-be/

Bell, C., Douce C. , Caeiro, S., Teixeira, A. Martín-Aranda, R. \& Otto,D. (2017). Sustainability and distance learning: a diverse European experience?. pages: 1-8. DOI: $10.1080 / 02680513.2017 .1319638$

Bogost, I. (2013). The condensed classroom [Blog Post]. The Atlantic. Retrieved from http://www.theatlantic.com/technology/archive/2013/08/the-condensedclassroom/279013/

Brabazon, T. (2007). The University of Google: Education in the post-information age. Aldershot.

Bradford, K. \& Loble, M. (2016). M. Classroom Hollywood: Using popular Entertainment to Engage New MOOC Audiences. MOOCs European Stakeholder Summit 2016. $365-373$

Cooch, M., Foster, H. \& Costello, E. (2015). Our Moocs with Moodle. Position paper for European cooperation on MOOCs. EADTU 2015

Creelman, A. (2014). The corridor of uncertainty. Norwegian Mooc Commission. Retrieved from http://acreelman.blogspot.de/2014/06/norwegian-mooccommission.html

Daniel, J. (2012). Making sense of MOOCs: Musings in a maze of myth, paradox, and possibility. Journal of Interactive Media in Education. Retrieved from http://jime.open. ac.uk/article/view/259

Economic Implications and Stakeholder Reactions in a Digital University Environment. Wolfram Laaser 
EADTU (2015). Position Paper for European Cooperation on Moocs. Jansen \& Texeira (Eds.), March 2015, Brussels

Endlich, A. \& Sohoni, V. (2017). Burned by the Bots: Why Automation is Stumbling. Digital Mc Kinsey, May 24, 2017

Gartner (2016). Gartner's 2016 Hype Cycle for Emerging Technologies Identifies Three Key Trends that Organizations Must Track to Gain Competitive Advantage. Newsroom, August 16, $2016 \quad$ Retrieved from http://www.gartner.com/newsroom/id/3412017

Hart, J. (2015). Learning in the Social Enterprise. Retrieved from http://c4lpt.co.uk/resources/litw/

Hassan, R. (2004). Media, Politics and the Network Society. McGraw-Hill Education. UK

Jansen, D. \& Schuwer, R. (2014). (eds). Institutional MOOC strategies in Europe. Status report based on a mapping survey conducted in October - December 2014. EADTU, February 2015

Jansen, D. \& Goes-Daniels (2016). Comparing Institutional MOOOC Strategies. EADTU 2015

Jones, B. (2017) eLearning Trends of 2017. eLearning Trends Art 23.2.2017

Laaser, W. (2008). Economics of Distance Educating onimn Reconsidered. The Turkish Online Journal of Distance Education (TODJE), Vol. 9, No. 3. July 2008

Laaser W. (2014). The rise and fall of the "Massively Open Online Courses" (Review article). SEEJPH 2014, posted: 11 November 2014. DOI 10.12908/SEEJPH-201433

Laaser, W. \& E.A.Toloza (2017) The Changing Role of Educational Video in Higher Distance Education, IRRODL Vol. 18, N.2 April 2017

Laaser, W (2011). Some structural changes on the way towards eUniversity. Turkish Online Journal of Distance Education, Jan. 2011, Vol. 12, No. 1

Larivière, V. , Haustein, S. \& Mongeon P. (2015). The Oligopoly of Academic Publishers in the Digital Era. PloS One, 10 (6); DOI: 10.1371

Li, F. \& Chen, X. (2012). Economies of Scope in Distance Education. IRRODL Vol. 13,3

Morgan, J. (2013). Universities challenged: The impact of Digital Technology on Teaching and Learning. Educational Innovation Position Paper, Universitas 21, 2013

Economic Implications and Stakeholder Reactions in a Digital University Environment. Wolfram Laaser 
NMC (2017). Horizon Report 2017 Higher Education Edition. Retrieved from https://www.nmc.org/publication/nmc-horizon-report-2017-higher-educationedition/

OEB News (2017). How do we make education a "practice of freedom"? - talking to Audrey Watters. OEB News

Rifkin J. (2016). Die Null Grenzkosten Gesellschaft. Fischer Verlag, Frankfurt

Rumble G. (2001). The Costs and Costing of Networked Learning. JALN Vol. 5 (2)

Shacklock, X. (2016). From Bricks to Clicks. The Potential of data analytics in higher education. Higher Education Commission, London

Sharples, M., de Roock, R., Ferguson, R., Gaved, M., Herodotou, C., Koh, E., KukulskaHulme, A., Looi, C-K, McAndrew, P., Rienties, B., Weller, M., Wong, L. H. (2016). Innovating Pedagogy 2016: Open University Innovation Report 5. Milton Keynes: The Open University

Shah, D. (2017) A Proposal to Put the 'M' Back in MOOCs, EdSurge News Oct. 24, 2017

Shy, O. (2001). The economics of network Industries. Cambridge University Press

Siemens, G. Gaševic \& Dawson, S. (2015). Preparing for the digital university: A review of the history and current state of distance, blended and online learning. Retrieved from http://linkresearchlab.org/preparingdigitaluniversity.pdf

Wagner, L. (1972). The Economics of the Open University. Higher Education 1. 2:159-183

Watters, A. (2017). What's on the Horizon (Still, again, always) for Ed-Tech. Retrieved from http://hackeducation.com/2017/02/16/horizon

Williams, K., Kear, K., \& Rosewell, J. (2012). Quality Assessment for E-learning: a Benchmarking Approach (2nd ed.). Heerlen, The Netherlands: European Association of Distance Teaching Universities (EADTU).

World Economic Forum (2016). Digital Media and Society: Implications in a Hyperconnected Era. Report, Geneva, Switzerland

Yerbamrung, P. (1994),The emerging electronic university: A study of student cost effectiveness Economics of Distance Education, Dharnarajan et al. (Eds.), Hongkong

Young, J.R. (2017). Udacity Official Declares MOOCs 'Dead'(Though the company still offers them). EdSurge News Oct. 12, 2017

Economic Implications and Stakeholder Reactions in a Digital University Environment. Wolfram Laaser 


\section{Notes on contributor}

Dr. Wolfram Laaser was "Akademischer Direktor" at the Centre for Distance Education of FernUniversität in Hagen, Germany. He is consultant and lectures face to face and/or online internationally.

Economic Implications and Stakeholder Reactions in a Digital University Environment. Wolfram Laaser 